Regular Articles

\title{
PTHrP-induced modifications of the sea bream (Sparus auratus) vertebral bone proteome
}

\author{
Liliana Anjos $^{\mathrm{a}, *}$, Ana S. Gomes ${ }^{\mathrm{a}, 1}$, Begoña Redruello ${ }^{\mathrm{a}, 2}$, Richard Reinhardt ${ }^{\mathrm{b}, 3}$, Adelino V. Canário ${ }^{\mathrm{a}}$ \\ Deborah M. Power ${ }^{a}$ \\ ${ }^{a}$ Comparative and Molecular Endocrinology Group, CCMAR, CIMAR Laboratório Associado, University of Algarve, Campus de Gambelas, 8005-139 Faro, Portugal \\ ${ }^{\mathrm{b}}$ Max-Planck-Institute for Molecular Genetics, Ihnestrasse 63-73, D-14195 Berlin, Germany
}

\section{A R T I C L E I N F O}

\section{Article history:}

Received 8 May 2012

Revised 3 April 2013

Accepted 28 May 2013

Available online 7 June 2013

\section{Keywords:}

Anabolism

Sea bream recombinant parathyroid

hormone related peptide

Teleost bone proteome

Calcium binding proteins

\begin{abstract}
A B S T R A C T
Endocrine factors play an essential role in the formation and turnover of the skeleton in vertebrates. In the present study sea bream vertebral bone transcripts for PTH1R and PTH3R were identified and the action of intermittent administration of parathyroid hormone related protein (PTHrP) on the proteome of vertebral bone was analysed. Treatment of immature sea bream (Sparus auratus, $n=6$ ) for 5 days with homologous recombinant PTHrP(1-125; $150 \mathrm{ng} / \mathrm{g}$ body weight) modified bone metabolism and caused a significant $(p<0.05)$ reduction in both tartrate resistant acid phosphatase (TRACP) and alkaline phosphatase (ALP) in relation to control fish. However, the ratio of TRACP: ALP in PTHrP treated fish (1.3 to $2.2 \mathrm{cf}$. control) suggested it had an anabolic response. A sea bream vertebral bone proteome of 157 protein spots was generated and putative identity assigned to 118 (75.2\%) proteins of which $72 \%$ had homology to proteins/transcripts from teleosts many of which have not previously been reported in teleost bone. Classification of bone proteins using gene ontology revealed those with protein or metal/ion (e.g., calcium, magnesium, zinc) binding ( 53\%) activities were most abundant. The expression of eight proteins was significantly $(p<0.05)$ modified in the vertebra of PTHrP treated compared to control fish; three were up-regulated, betainehomocystein S-methyltransferase, glial fibrillary acidic protein, parvalbumin beta and five were down-regulated, annexin A5, apolipoprotein A1, myosin light chain 2, fast skeletal myosin light chain 3, troponin C. In conclusion, intermittent administration of PTHrP to sea bream is associated with an anabolic response in vertebral bone metabolism and modifies calcium binding proteins in the proteome.
\end{abstract}

(c) 2013 Elsevier Inc. All rights reserved.

\section{Introduction}

Skeletal tissue in vertebrates is a dynamic and highly specialized connective tissue and an important reservoir of minerals such as calcium (Ca), phosphorus ( $\mathrm{P}$ ) and magnesium (Mg). Teleost bone, is generally acellular and consists of hydroxyapatite embedded in a protein matrix in which, in contrast to the cellular bone of other vertebrates, the apatite crystals are smaller and poorly crystallized (Moss, 1961). In teleost fish the contribution of bone turn-

\footnotetext{
* Corresponding author. Fax: +351 289800069.

E-mail addresses: lanjos@ualg.pt (L. Anjos), Ana.Gomes@bio.uib.no (A.S. Gomes), bredruel@ipla.csic.es (B. Redruello), Reinhardt@mpipz.mpg.de (R. Reinhardt), acanario@ualg.pt (A.V. Canário), dpower@ualg.pt (D.M. Power).

1 Present address: Department of Biology, University of Bergen, Pb 7803, 5020 Bergen, Norway.

2 Present address: Instituto de Productos Lácteos de Asturias (IPLA), Consejo Superior de Investigaciones Científicas (CSIC), Carretera de Infiesto s/n, 33300 Villaviciosa, Asturias, Spain.

3 Present address: Max Planck-Genome Centre, Max Planck-Institute for Plant Breeding Research, Carl-von-Linné-Weg 10, D-50829 Köln, Germany.
}

over to Ca homeostasis is uncertain as Ca is taken up from food and the surrounding water via the intestine and gills (see review by Guerreiro et al. (2007)). This is one of the reasons why a phosphorous rather than Ca-driven mineral homeostasis has been proposed for teleost fish (Hall, 2005; Lall, 2002; Witten and Huysseune, 2009). The regulatory mechanisms of Ca homeostasis in teleosts are complex and involve several factors, including stanniocalcin (STC), calcitonin (CT) and 1,25-dihydroxycholecalciferol and parathyroid related protein (PTHrP) (Bonga and Pang, 1991; Fuentes et al., 2010).

One of the calcitropic effects of PTHrP is likely to be through its actions on bony tissue as it stimulates osteoclast-specific tartrateresistant acid phosphatase (TRACP) activity in fish scales through PTH1R (Rotllant et al., 2005) and it also modifies transcription of genes involved in matrix production and mineralization (Redruello et al., 2005). In teleost fish, PTH and PTHrP isoforms are products of duplicated genes and bring about their effect by interacting with two different G-protein-coupled receptors (GPCRs), known as PTH1R and PTH3R. Pharmacological characterization of the zebrafish (Danio rerio) receptors (Rubin et al., 1999) indicates that PTH 
and PTHrP both activate PTH1R (Rubin et al., 1999), which is the principal receptor in the vertebrate skeleton (Juppner et al., 1991; Karaplis and Deckelbaum, 1998; Rotllant et al., 2005). PTH3R, which has no orthologue in mammals, is activated by PTHrP with similar potency the PTH1R (Rubin and Juppner, 1999). In mammals, depending on the physiological status of the animal and regime of administration (e.g., continuous or intermittent), PTH and PTHrP can have both anabolic and catabolic effects on bone in vivo (Swarthout et al., 2002). The response of mammalian bone to PTH has been characterized at the level of the transcriptome and proteome (Li et al., 2007; Sun et al., 2009; Swarthout et al., 2002). Studies of PTHrP are restricted to the transcriptome of chondrocytes (growth plate, hypertrophic) and in mammals responsive genes include components of the extracellular matrix and molecules implicated in signal transduction and regulation of transcription (Hoogendam et al., 2007, 2006).

In teleost fish PTHrP rather than PTH mobilises Ca from bony tissue and the present study reports for the first time its action on the skeleton by analysing changes in the proteome. Post-cranial dermal skeleton is suggested to be most susceptible to turnover (Witten and Huysseune, 2009) and so vertebra from sea bream exposed to biologically active sea bream recombinant PTHrP(1-125) (Anjos et al., 2005) were studied. Bone turnover in response to PTHrP was assessed by measuring markers of osteoclasts and osteoblasts, respectively, TRACP and ALP. A partial sea bream (Sparus auratus) vertebral bone proteome was established using $2 \mathrm{D}$ electrophoresis coupled to MALDI-TOF analysis and proteins modified by intermittent treatment with PTHrP were identified.

\section{Methods}

\subsection{Experimental procedure and sampling}

Maintenance and manipulation of animals used in the study was carried out in accordance with Portuguese legislation for the use of laboratory animals under a Group-1 license from the Direcção-Geral de Veterinária, Ministério da Agricultura, do Desenvolvimento Rural e das Pescas.

Immature sea bream (body weight $70.6 \pm 9.8 \mathrm{~g}$; total length $15.1 \pm 0.7 \mathrm{~cm}$ ) were obtained from a fish farm (TIMAR, Cultura de Águas, Olhão, Portugal). Fish were acclimated for several months in Ramalhete Marine Experimental Station (Universidade do Algarve, Faro, Portugal) in $500 \mathrm{~L}$ tanks supplied with a continuous flow of oxygenated sea water of $35 \%$ salinity, under a $12: 12 \mathrm{~h}$ light-dark photoperiod and at a water temperature of $12 \pm 1{ }^{\circ} \mathrm{C}$. Fish were fed once a day with $1 \%$ body weight commercial dry pellets (PROVIMI, Portugal).

To establish if PTH1R and PTH3R are transcribed in vertebral tissue two immature sea bream were killed by decapitation after anaesthesia with 2-phenoxyethanol in seawater (1:10,000 v/v; Sigma-Aldrich, USA). Fish were rapidly dissected and vertebra centrum collected and immediately frozen at $-80^{\circ} \mathrm{C}$ for subsequent RNA extraction.

For PTHrP treatments, sea bream ( $n=6 /$ tank) were randomly assigned to two $200 \mathrm{~L}$ tanks and maintained for one week prior to the start of the experiment under the same conditions as those indicated above. Fish in one tank (body weight $69 \pm 5.7 \mathrm{~g}$; total length $15.1 \pm 0.5 \mathrm{~cm}$ ) were given daily intra-peritoneal (ip) injections over 5 days of physiological saline containing $150 \mathrm{ng} / \mathrm{g}$ body weight of recombinant homologous PTHrP(1-125) in $100 \mu$ l saline (Anjos et al., 2005). The dose, duration and mechanism of administration of PTHrP(1-125) was chosen based on previous studies in mammals (Kim et al., 2005; Sun et al., 2009) and in vitro studies of PTHrP in teleosts (Redruello et al., 2005; Rotllant et al., 2005, 2003 ) and sea bream bone responsiveness to SERMs in vivo (Vieira et al., 2012). In the other tank control fish (body weight $72.3 \pm 3.7 \mathrm{~g}$; total length $15.2 \pm 0.9 \mathrm{~cm}$ ) received ip injections of physiological saline only. Twenty-four hours after the last hormone injection the fish were anaesthetized as indicated above, weighed and measured. Fish were killed by decapitation and vertebra 16 and 17 , localized in the region below the last dorsal fin ray (Fig. 1), were dissected out, immersed in ice cold $1 \times$ PBS $(137 \mathrm{mM}$ $\left.\mathrm{NaCl}, 2.7 \mathrm{mM} \mathrm{KCl}, 100 \mathrm{mM} \mathrm{Na}_{2} \mathrm{HPO}_{4}, 2 \mathrm{mM} \mathrm{KH} \mathrm{PO}_{4}, \mathrm{pH} 7.4\right)$ containing protease inhibitor cocktail $(1 \mathrm{ml} / 20 \mathrm{~g}$ tissue; Sigma-Aldrich, US) and dissected free of soft tissue. Cleaned vertebras were snap-frozen in liquid nitrogen and stored at $-80^{\circ} \mathrm{C}$ until analysis.

\subsection{RNA extraction, $C D N A$ synthesis and RT-PCR}

Total RNA extractions were carried out using the Maxwell ${ }^{\circledR} 16$ System (Promega, USA) following the manufacturer's instructions after pulverization of the frozen vertebra $(n=2)$ using a mortar and pestle in the presence of liquid nitrogen. Quantification and quality of RNA was determined by spectrophotometry (NanoDrop 1000 Spectrophotometer, Thermo Fisher Scientific, USA) and electrophoresis on $1.5 \%$ agarose gels. Total RNA $(2-3 \mu \mathrm{g})$ was treated with DNase using a DNA-free kit (Ambion, UK) and cDNA synthesis was carried out as described in Vieira et al. (2012).

Sea bream PTH1R and PTH3R cDNA (GeneBank ID: AJ619024 and AY547261) were amplified using specific primer pairs: PTH1Rafw (5'-TCACCAACGTCACTGCCAGAGGA-3' and PTH1Rbrv (5'-TGTCCC GACGAGGGTATCGAGTT- $3^{\prime}$ ) and PTH3Rfw 1 (5'-ACATCCACAT TCACTTCTTCAC-3')/PTH3Rrv2 5'-GATGAGGGCCACAGGTAGT-3'). The cycling conditions were: $3 \mathrm{~min}$ at $95^{\circ} \mathrm{C}, 32$ cycles of amplification $\left(20 \mathrm{~s}\right.$ at $95^{\circ} \mathrm{C}, 20 \mathrm{~s}$ at $55-53^{\circ} \mathrm{C}$ and $30 \mathrm{~s}$ at $\left.72^{\circ} \mathrm{C}\right)$ and a final elongation step of $5 \mathrm{~min}$ at $72^{\circ} \mathrm{C}$ in a $\mathrm{T} 100^{\mathrm{TM}}$ Thermal Cycler (Bio-Rad, Portugal) (Rotllant et al., 2005). This protocol runs a non-saturated product amplification of $142 \mathrm{bp}$ and $250 \mathrm{bp}$ for PTH1R and PTH3R, respectively. Amplified products $(15 \mu \mathrm{l})$ were run on a Tris-borate-EDTA (1.3\%) agarose gel containing ethidium bromide. Beta actin ( $\beta$-actin), which has a constant expression in vertebra, was chosen as the reference gene and a $250 \mathrm{bp}$ product was amplified. The reaction conditions were the same as those for PTH1R and PTH3R with the exception of the annealing temperature $\left(60^{\circ} \mathrm{C}\right)$ and the number of cycles $(22)$. The reaction products were sequenced to confirm their identity.

\subsection{Plasma analysis}

Calcium and PTHrP levels were determined in individual plasma samples from sea bream of PTHrP treated and control fish. A

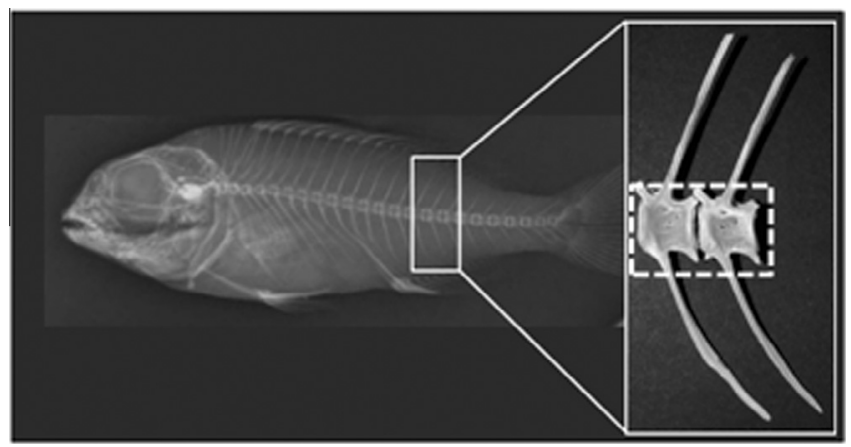

Fig. 1. X-ray of a juvenile sea bream revealing the calcified skeleton. The region from which vertebra were removed for protein extraction is boxed in white and a photograph shows a lateral view of the vertebra with associated neural and haemal arches at a higher magnification $(\times 20)$. 
colorimetric assay adapted to microplates was used to measure total plasma calcium (Ca kit procedure no. 587, Sigma-Aldrich) in duplicate $2.5 \mu \mathrm{l}$ plasma samples. Circulating levels of PTHrP were measured in the same plasma samples using a piscine-specific RIA as described by Rotllant et al. (2003).

\subsection{Tartrate-resistant acid phosphatase (TRACP) and alkaline phosphatase (ALP) activity}

To assess if PTHrP modified sea bream vertebral bone metabolism, TRACP and ALP were measured using a modification of the method initially developed for fish scales by Persson et al. (1995) and Suzuki et al. (2000) and previously detailed for sea bream (Guerreiro et al., 2002; Rotllant et al., 2005). Briefly, 50-70 mg of frozen vertebra from individual fish ( $n=6$ per group) were pulverised into a fine powder in liquid nitrogen using a mortar and pestle. The powdered vertebra was resuspended in $0.5 \mathrm{ml}$ of cold $0.1 \mathrm{M}$ sodium acetate buffer ( $\mathrm{pH} 5.0$ ), sonicated, centrifuged at $7000 \mathrm{~g}$ for $20 \mathrm{~min}$ at $4{ }^{\circ} \mathrm{C}$ and the supernatant removed and used to measure the enzyme activity. Assays to determine TRACP and ALP activity in vertebra were carried out in duplicate. TRACP activity was determined by adding $50 \mu \mathrm{l}$ of vertebral extract to $350 \mu \mathrm{l}$ of $10 \mathrm{mM}$ para-nitrophenyl-phosphate (pNPP; Sigma-Aldrich, USA) and $20 \mathrm{mM}$ tartrate in NaAc buffer $(0.1 \mathrm{M}, \mathrm{pH} 5.3)$ and incubating for $30 \mathrm{~min}$ at $22{ }^{\circ} \mathrm{C}$. The reaction was stopped by adding $200 \mu \mathrm{l}$ of $2 \mathrm{M} \mathrm{NaOH}$ and the solution was centrifuged for $5 \mathrm{~min}$ at $3600 \mathrm{~g}$ and the absorbance measured at $405 \mathrm{~nm}$. The quantity of para-nitrophenol (pNP; Sigma-Aldrich, USA) produced was determined using a standard curve for pNP. ALP activity was measured using the same procedure as for TRACP with the exception that an alkaline buffer (100 mM Tris- $\mathrm{HCl}$, pH 9.5; $1 \mathrm{mM} \mathrm{MgCl}_{2} ; 0.1 \mathrm{mM} \mathrm{ZnCl}$ ) was used.

\subsection{Vertebra proteome analysis}

\subsubsection{Protein extraction}

Optimization studies for protein extraction and resolution by 2 dimensional electrophoresis (2-DE) guided the selection of experimental conditions utilized. Preliminary optimization of protein extracts and protein concentration was carried out using 340 or $700 \mu \mathrm{g}$ of total protein with IPG strips in a pH range of 3-10 or 4-7 and the latter was selected together with $340 \mu$ g of total protein. Demineralizing acid extraction (Jiang et al., 2007) and nondemineralizing (Fan et al., 2005) methods were tested and the latter selected as it yielded a higher number of proteins, which were better resolved by 2 -DE. In brief, total protein was extracted (200$300 \mathrm{mg}$ of frozen tissues) from pulverised vertebra ( $n=6$ per group, the same individuals as in TRACP and ALP analysis) ressuspended in $0.5 \mathrm{ml}$ of ice-cold extraction buffer (30 mM Tris- $\mathrm{HCl}, \mathrm{pH}$ 7.4 containing $7 \mathrm{M}$ urea, $2 \mathrm{M}$ thiourea, $4 \%$ CHAPS) containing a protease inhibitor cocktail ( $1 \mathrm{ml} / 20 \mathrm{~g}$ tissue, Sigma-Aldrich, USA). The homogenates were sonicated twice for $10 \mathrm{~s}$, incubated on ice for $1 \mathrm{~h}$ with gentle agitation, centrifuged at $45,000 \mathrm{~g}$ for $45 \mathrm{~min}$ at $4{ }^{\circ} \mathrm{C}$ and the supernatant removed. The protein content of the vertebral bone extract was quantified using the Bradford method (BioRad, USA).

\subsubsection{Two-dimensional gel electrophoresis (2-DE)}

For two dimension gel electrophoresis (2-DE), vertebral bone extracts $(340 \mu \mathrm{g}$ total protein) were centrifuged for $30 \mathrm{~min}$ $\left(22,000 \mathrm{~g}, 4^{\circ} \mathrm{C}\right)$ to remove insoluble aggregates, and the protein extract precipitated with acetone and ressuspended in $350 \mu \mathrm{l}$ of rehydration buffer (7 M urea, $2 \mathrm{M}$ thiourea, $4 \% \mathrm{w} / \mathrm{v}$ CHAPS, $0.002 \%$ bromophenol blue, $10 \mathrm{mM}$ DTDE, 2\% v/v IPG buffer pH 47). Isoelectric focusing (IEF) was performed using a Multiphor II Electrophoresis System (GE-Healthcare Life Systems, UK), accord- ing to the manufacturer's instructions with $18 \mathrm{~cm}$ IPG strips with a $\mathrm{pH}$ range of 4-7 (Amersham Biosciences, Spain). Samples were loaded onto the IPG strips covered by immobiline DryStrip Cover Fluid and rehydrated for $20 \mathrm{~h}$ at room temperature in a re-swelling tray channel (Serva, Portugal). Subsequently, IEF (first dimension) was performed at $20^{\circ} \mathrm{C}$ using the following electrophoresis protocol: $0.01 \mathrm{~h}$ at $500 \mathrm{~V}$ and $0.001 \mathrm{KVh} ; 6 \mathrm{~h}$ at $500 \mathrm{~V}$ and $3 \mathrm{KVh} ; 1.30 \mathrm{~h}$ at $3500 \mathrm{~V}$ and $3 \mathrm{KVh} ; 8 \mathrm{~h}$ at $3500 \mathrm{~V}$ and $20 \mathrm{KVh}$. IPG strips with fractionated proteins were then equilibrated and reduced for $15 \mathrm{~min}$ (50 mM Tris-HCl pH 8.8, $100 \mathrm{mM}$ DTT, $6 \mathrm{M}$ urea, 30\% v/v glycerol, $2 \% \mathrm{w} / \mathrm{v}$ SDS, $1 \% \mathrm{w} / \mathrm{v}$ bromophenol blue) followed by alkylation for $15 \mathrm{~min}$ in the same buffer without DTT and supplemented with $135 \mathrm{mM}$ iodoacetamide.

Second dimension electrophoresis was performed using an ETTAN DALT six vertical system (GE Healthcare, Germany) following the manufacturer's instructions. Equilibrated IPG strips were transferred to $12.5 \%$ SDS-PAGE gels $(24 \times 18 \mathrm{~cm})$ and proteins separated by applying $10 \mathrm{~mA} /$ gel for $30 \mathrm{~min}$ followed by $40 \mathrm{~mA} / \mathrm{gel}$ for a further $6 \mathrm{~h}$ at $20^{\circ} \mathrm{C}$. A pre-stained Protein Ladder (PageRuler,Fermentas, US) was included in all electrophoresis. The resolved proteins were fixed for $30 \mathrm{~min}$ in $40 \% \mathrm{v} / \mathrm{v}$ methanol containing $10 \%$ $\mathrm{v} / \mathrm{v}$ acetic acid and stained overnight using Coomassie blue R $(40 \%$ v/v methanol; $10 \%$ v/v acetic acid; $0.1 \%$ w/v Coomassie blue R 250 , Sigma-Aldrich, USA). The gels were destained in $10 \% \mathrm{v} / \mathrm{v}$ acetic acid and $40 \% \mathrm{v} / \mathrm{v}$ methanol for $12 \mathrm{~h}$ before image analysis.

\subsubsection{Gel image analysis}

Coomassie blue stained gels were scanned in a calibrated ImageScanner $^{\mathrm{TM}}$ III densitometer (GE Healthcare, Germany) and digital images (at 300 dpi resolution) captured using Labscan 6.0 software (GE Healthcare, Germany). The images were saved as uncompressed TIFF or MEL files. Differential gel image analysis was carried out using ImageMaster ${ }^{\mathrm{TM}}$ 2D Platinum software, version 6.0 (GE Healthcare, Sweden). Three gels, each containing a pool of vertebral extracts from 2 fish, were analysed per group (control and PTHrP). Pooled extracts were required to attain an adequate concentration of protein for electrophoresis. A consensus proteome was obtained by matching proteins on the 3 gels using the automatic setting of the software followed by manual matching and editing to remove artefacts. Normalized values of protein spot area (\% total area of spots), intensity (\% total spots intensity) and volume (\% total spots volume) were obtained.

Differential expression of proteins between PTHrP treated or control fish was obtained as the difference in normalized protein spot values between the two groups. A 2-fold difference in the average protein spot volume ratio between control and treated animals was considered significant. For unmatched protein spots between PTHrP treatment and control those with an intensity $>0.5 \%$ compared to background were included in the analysis. To enhance resolution, manual spot-by-spot supervision was carried out to correct over- or under-detected spots, and to validate candidate protein spot localisation and relative abundance on each of the triplicate gels.

\subsection{MALDI-TOF analysis}

\subsubsection{In-gel trypsin digestion}

To establish the proteome of sea bream vertebra, differentially expressed protein spots and randomly picked protein spots were excised from the gel, taking a mix of spots representing proteins with different expression levels, molecular mass and isoelectric point. Excised protein spots were washed, reduced, dehydrated and alkylated and subject to in gel tryptic digestion using $2 \mu \mathrm{l}$ of trypsin solution ( $10 \mathrm{ng} / \mu \mathrm{l}$ trypsin in $50 \mathrm{mM} \mathrm{NH}_{4} \mathrm{CO}_{3} \mathrm{pH} 7.8$, Roche Applied Science, US) for $30 \mathrm{~min}$ at $4{ }^{\circ} \mathrm{C}$. Subsequently, $10 \mu \mathrm{l}$ of $50 \mathrm{mM} \mathrm{NH}_{4} \mathrm{CO}_{3}$ ( $\mathrm{pH} 7.8$ ) buffer was added to each sample, and 
the digestion was performed at $37{ }^{\circ} \mathrm{C}$ overnight. Digestions were stopped by addition of $10 \mu \mathrm{l}$ of extraction buffer $(0.5 \% \mathrm{v} / \mathrm{v}$ trifluoroacetic acid, $0.2 \mathrm{mM}$ n-octylglycopyranoside) and samples were analysed by MALDI-TOF mass spectrometry (MS, BrukerDaltonics, Germany) using automated procedures.

\subsubsection{Protein identification}

MALDI sample preparation was performed on MALDI 600-384 AnchorChip sample plates (BrukerDaltonics, Germany). The trypsin digested samples $(1 \mu \mathrm{l})$ were deposited onto pre-formed microcrystalline layers of the MALDI matrix a-cyano-4-hydroxycinnamic acid. Mass spectra of positive ions in the $m / z$ range $640-4000$ were recorded on an Ultraflex LIFT and a Reflex III MALDI-TOF mass spectrometer (BrukerDaltonics, Germany) operated in the reflector mode using delayed ion extraction. Fragment ion mass spectra of selected peptides were used for verification of uncertain identification results. Selection of the first monoisotopic signals in the spectra was performed using the signal detection algorithm SNAP implemented in the FlexAnalysis software (BrukerDaltonics, Germany). The spectra was calibrated and filtered, based upon a combination of external (using polyethanolglycol) and internal calibration using the signal from tryptic autodigestion products (monoisotopic masses $\left(\mathrm{MH}^{+}\right)$) and two peptide standards (human angiotensin I and human ACTH-(18-39); 1296.6853 and 2465.1989 Da, respectively).

\subsubsection{Database search}

Protein identification was performed with the MASCOT data base search engine (version 1.8; http://www.matrixscience.com) using combined PMF and MS/MS peak list data sets via BioTools 2.3 software (BruckerDaltonics, Germany). Searches were carried out against the GenBank non-redundant (nr) (http:// www.ncbi.nlm.nih.gov/) and SwissProt (http://www.ebi.ac.uk/uniprot/) Actinopterygii sequences assuming the following parameters: (1) fixed and variable modifications were carbamidomethyl of cysteine and oxidation of methionine, respectively; (2) formation of single charged peptides with up to 1 missed cleavages; (3) peptide tolerance of $100 \mathrm{ppm}$ and $0.25 \mathrm{Da}$, respectively, for MS and MS/MS spectra. To increase the number of protein matches searches were also performed against sea bream (taxid: 8175 ) and sea bass (taxid:13489) ESTs from GenBank (assessed December 2009). PMF and MS/MS spectra were accepted as valid when the E-value was below 0.05 .

Further analysis of the proteome of sea bream vertebra was carried out by assigning Gene Ontology (GO) classifications through UniProt and GeneCards (http://www.genecards.org/) to identified proteins. The GOSlim Viewer (http://www.agbase.msstate.edu/index.html) was used to analyze assigned function.

\subsection{Statistical analysis}

Plasma parameters and TRACP/ALP activity was analyzed by one-way analysis of variance (ANOVA) (SigmaStat Software V3.5) after assessing normality and homogeneity of variance. Statistical significance was considered at $p<0.05$ and data are presented as mean \pm standard error of the mean (SEM). For proteomics the mean, standard error of the mean (SEM) and mean square deviation (MSD) were determined for all selected normalized protein spots. Comparison between protein spot volume of control and PTHrP treated samples was carried out using a Student's $t$-test and a level of significance of 5\%. The statistical tests for proteomics were performed within the ImageMaster ${ }^{\mathrm{TM}}$ 2D Platinum software and using SigmaStat Software V3.5.

\section{Results}

\subsection{PTHrP tissue responsiveness}

\subsubsection{Expression of PTH1R and PTH3R in vertebra tissue}

RT-PCR revealed that sea bream vertebral bone contains transcripts for both PTH1R and PTH3R (Fig. 2) and confirm that it is a target tissue for PTHrP action. None of the control reactions (absences of cDNA or absence of reverse transcriptase in cDNA synthesis) gave a reaction product (Fig. 2).

\subsubsection{Effects of PTHrP on plasma parameters}

The circulating levels of PTHrP and total calcium (Ca) were measured $24 \mathrm{~h}$ after the last treatment of PTHrP(1-125). Plasma PTHrP was not significantly different in PTHrP(1-125) treated fish $(0.370 \pm 0.025 \mathrm{ng} / \mathrm{ml})$ compared to control fish $(0.379 \pm 0.029 \mathrm{ng} /$ $\mathrm{ml})$. Similarly, plasma Ca was not significantly modified between PTHrP(1-125) treated fish $(2.702 \pm 0.0423 \mathrm{mM})$ and control fish (Ca- $2.491 \pm 0.157 \mathrm{mM}$ ).

\subsubsection{TRACP and ALP activities in sea bream vertebra}

TRACP activity in vertebra was significantly suppressed by intermittent treatment with $\mathrm{PTHrP}(1-125)(p<0.05, n=6$; Fig. 3$)$. TRACP activity dropped from $8.8 \pm 1.83 \mathrm{nmolpNP}$ produced $/ \mathrm{mg} / \mathrm{h}$ in control fish to $3.6 \pm 0.66 \mathrm{nmolpNP}$ produced $/ \mathrm{mg} / \mathrm{h}$ in PTHrP treated fish. ALP activity was also significantly reduced $(p<0.05, n=6$; Fig. 3$)$ in vertebra of PTHrP treated fish and was $2.7 \pm 0.24$ nmolpNP produced/ $\mathrm{mg} / \mathrm{h}$ compared to $4.0 \pm 0.40 \mathrm{nmolpNP}$ produced $/ \mathrm{mg} / \mathrm{h}$ in control fish. The ratio of TRACP:ALP in vertebra from control fish was 2.2 and in vertebra from PTHrP treated fish was 1.3 suggesting it provoked a shift to an anabolic state.

\subsection{Partial characterization of sea bream vertebra proteome}

A large proportion of the proteins extracted from sea bream vertebral bone were acidic and had a $\mathrm{pI}$ between 4-7 and a molecular weight range between $10-100 \mathrm{kDa}$ (Fig. 4). Approximately 300 protein spots were detected after Coomassie blue staining. Of 157 protein spots identified by 2-DE and analysed by MALDI-TOF (see Supplementary Table 1 ), the peptide mass fingerprint (PMF) and mass peak spectra obtained for 32 (20.4\%) were of low resolution and could not be identified. Of the remaining 125 proteins, 75 (60\%) gave a positive match $\left(\mathrm{e}^{-5}\right)$ against the NCBI non-redundant nucleotide database. The remaining 50 proteins (40\%) were putatively identified from database searches of PMF and MS/MS mass peak spectra against the SwissProt and sea bream and sea bass

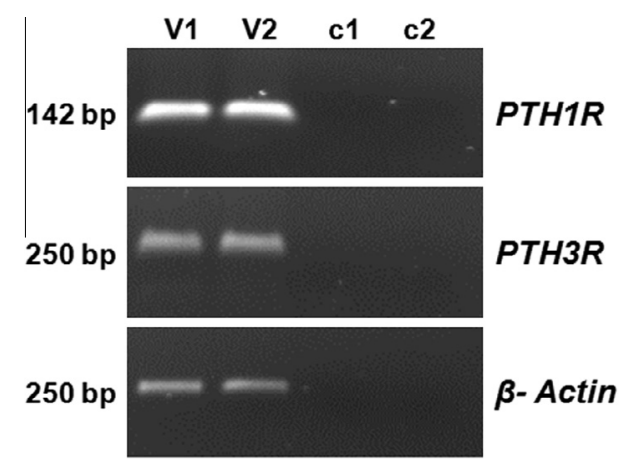

Fig. 2. Transcript abundance of $P T H 1 R$ and $P T H 3 R$ receptors in sea bream vertebra. Specific RT-PCR was used to amplify sea bream PTH1R and PTH3R in mRNA extracts from the vertebra of two individuals (V1 and V2). Beta actin ( $\beta$-actin) was used as a reference to control the quantity cDNA included in PCR reactions. Control samples: c1 - cDNA synthesis reactions lacking reverse transcriptase, and c2 - PCR reaction lacking cDNA. Molecular sizes in base pairs (bp) are indicated on the left hand side. 


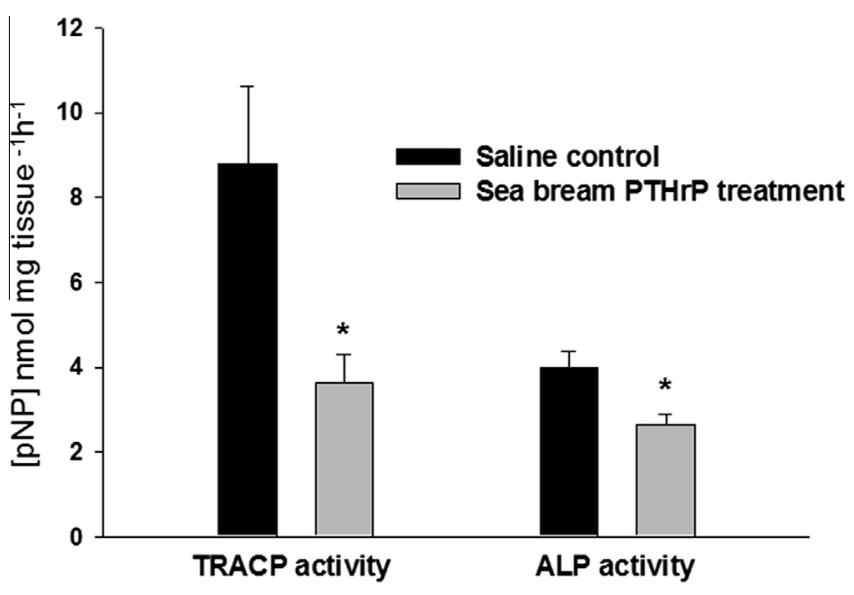

Fig. 3. TRACP and ALP activity in the vertebra of immature sea bream after 5 days of intermittent treatment with sea bream recombinant PTHrP(1-125) (150 ng/g body weight) or saline (control). Data represent the mean \pm SEM of six biological replicates measured twice independently with two technical replicates per measurement and the results are expressed as nmol pNP produced $\mathrm{h}^{-1} \mathrm{mg}^{-1}$ of vertebra. ${ }^{*}$ Indicates that a statistically significant difference exists $(p<0.05)$.

ESTs. Overall, 118 (94.4\%) proteins matched named proteins and the remaining (5.6\%) were unnamed and $72 \%$ of the proteins identified were homologous to proteins/transcripts identified in fish.

In general, the proteins extracted from the sea bream vertebra were more acidic than their mammalian homologues. Notable differences in $\mathrm{pI}$ between fish and mammalian proteins were found for myosin-binding protein $\mathrm{H}$ (spot 114 ; pI predicted 12.3 and determined 5.6), phosphatidylethanolamine-binding protein 1 (spot 7E; pI predicted 12.5 and determined 5.6), fibrinogen alpha chain precursor (spot 1I; pI predicted 12.7 and determined 6.5) and annexin A5 (spot 50; pI predicted 12.6 and determined 5.3) (see Supplementary Table 1 ). Approximately $20 \%$ of the proteins detected in the sea bream vertebral bone proteome corresponded to isoforms of the same protein with differing MW and $\mathrm{pI}$ (e.g., glial fibrillary acidic protein).

\subsection{Grouping of protein by putative function}

Classification by molecular function of proteins identified in the bone proteome (Fig. 5A and Supplementary Table 1) revealed that the main category was proteins with binding activity (53\%). Binding activity was subdivided into: general binding (13\%), which included lipocalin precursor and S-adenosylhomocysteine hydrolase and binding of: calcium (9\%); proteins (9\%); nucleotides (9\%); actin (6\%); lipids (5\%); carbohydrates (1\%) and receptor binding (1\%). These categories contained annexin A5, 40S ribosomal protein S24, Profilin-2, Calmodulin, Beta-soluble NSF attachment protein, 14-3-3-like protein, Protein S100-A11, Apolipoprotein A-I Precursor and retinol binding protein $1 \mathrm{a}$. The second most abundant category was catalytic activity (13\%), hydrolases (8\%) and structural molecule activities (8\%). The latter categories included ubiquitin carboxyl-terminal hydrolase, betaine-homocysteine S-methyltansferase, caldecrin precursor and collagen alpha-2(I) chain precursor.

In consideration of the importance of ion binding proteins in bone a more detailed evaluation of this group was made. This category contained $28 \%$ of the total proteins identified in the bone proteome (Table 1) and Ca binding proteins were most abundant (57\%) and included parvalbumin beta, protein S100-A11 and annexin A3. The second most abundant proteins in this group bound magnesium (20\%) and included for example, the enzyme Phosphoglucomutase 1 . A lower percentage of proteins were classified as "other metal binding proteins" (14\%) and zinc binding proteins (9\%) and these last categories included for example, transferrin, selenium-binding protein 2 and two forms of Carbonic anhydrase, respectively (Fig. 5B and Table 1).

\subsection{PTHrP induced differential expression of proteins}

Eight protein spots extracted from the vertebra had reproducible and statistically significant $(p<0.05)$ differences in abundance ( $\geq 2$-fold change) between PTHrP treated and control sea bream (Figs. 4 and 6). Proteins up-regulated by PTHrP were betaine-homocystein S-methyltransferase, glial fibrillary acidic protein and parvalbumin beta and those down-regulated were annexin A5, apolipoprotein A1, myosin light chain 2, fast skeletal myosin light
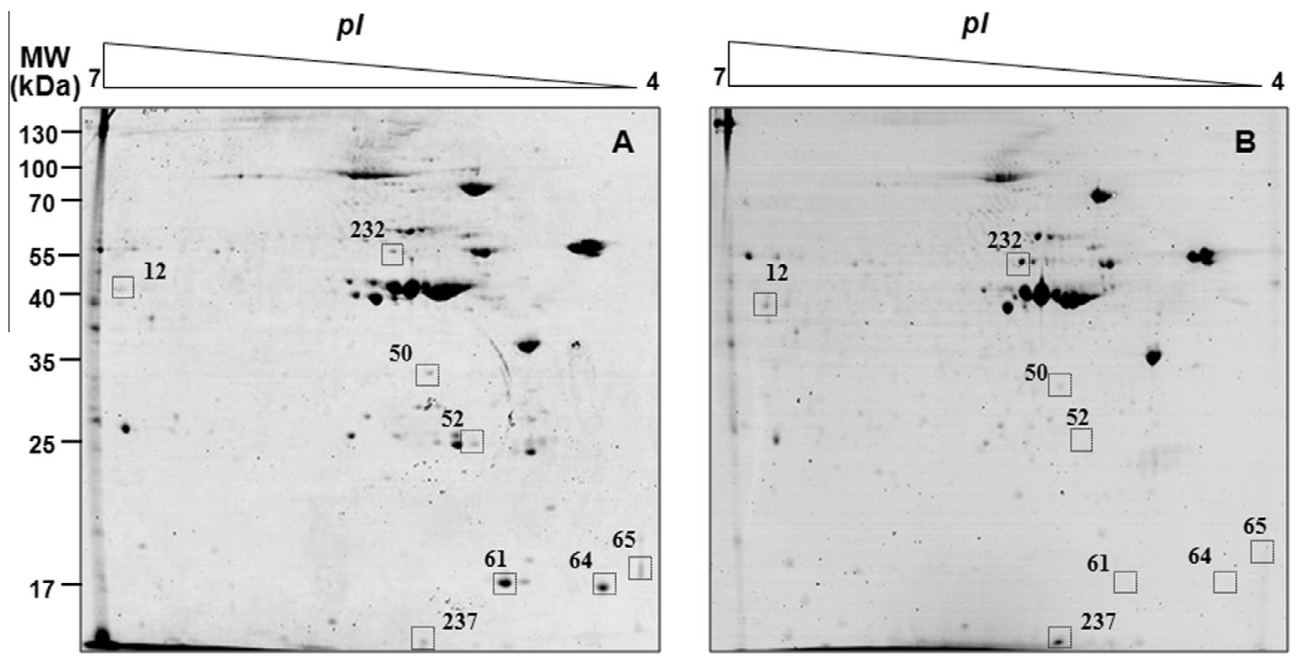

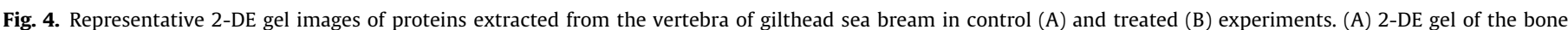

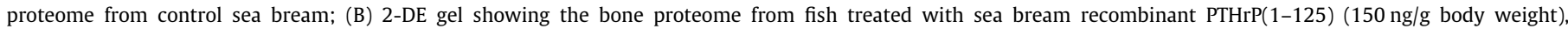

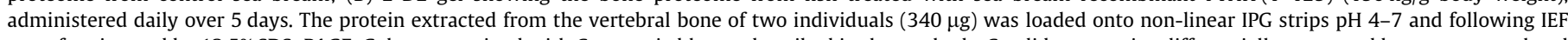

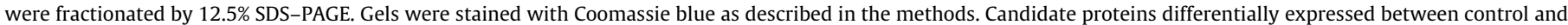

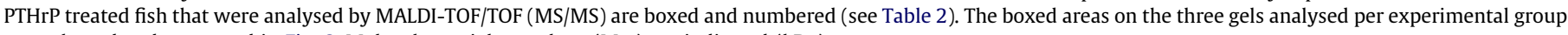
are enlarged and presented in Fig. 6. Molecular weight markers (Mw) are indicated (kDa). 
A

\section{Molecular function}

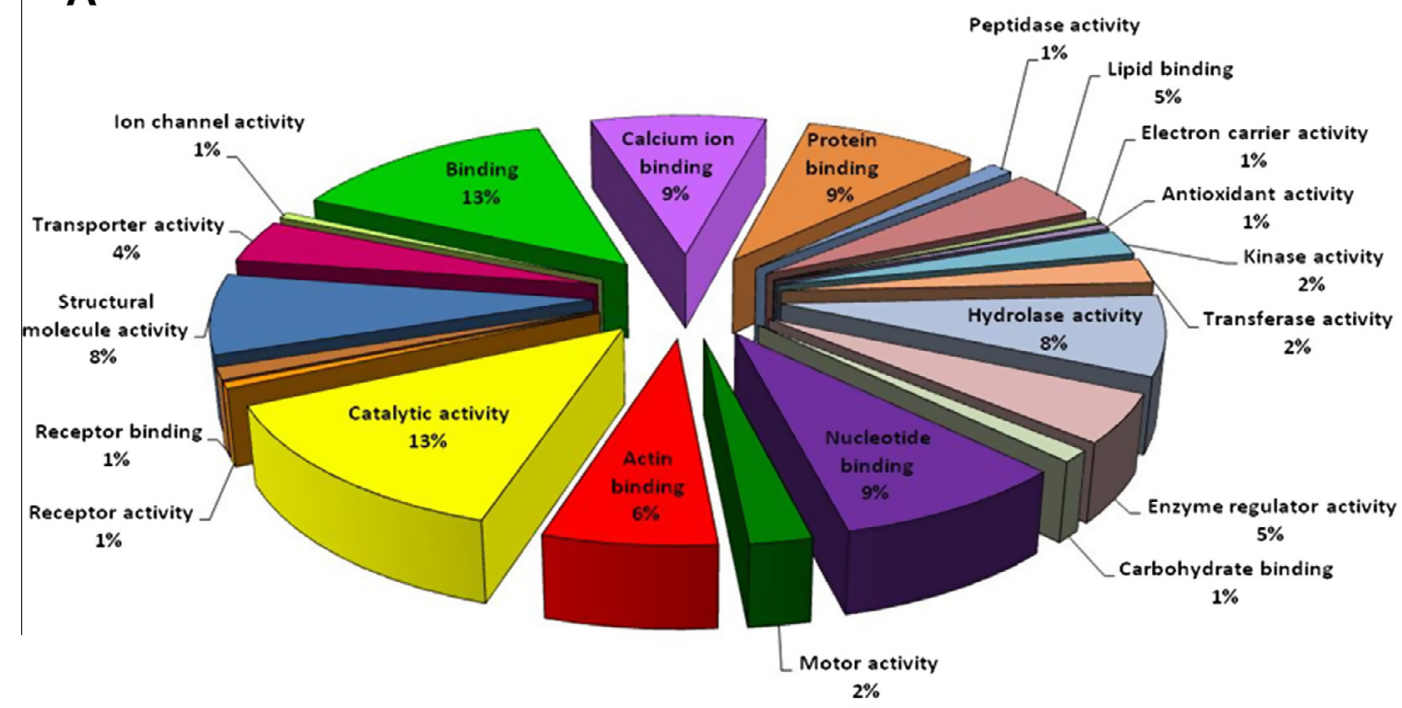

B

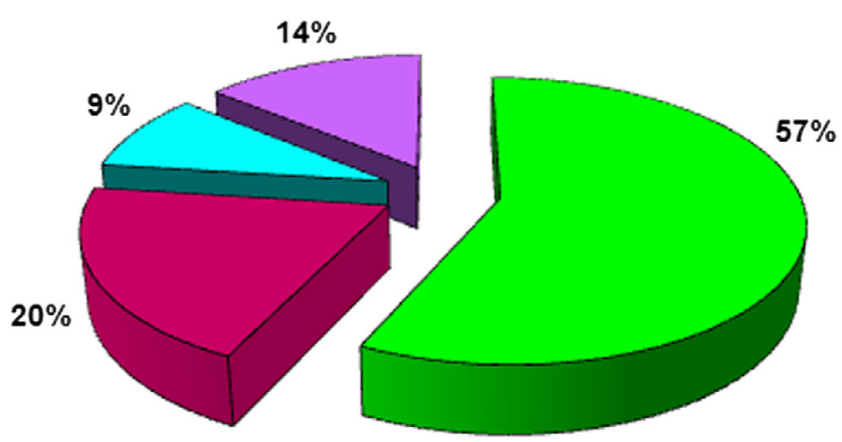

口Calcium $\square$ Magnesium $\square$ Zinc 口Otherlons

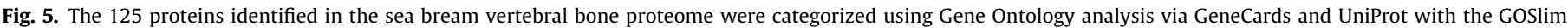

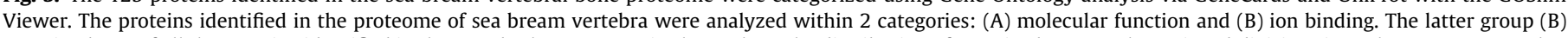

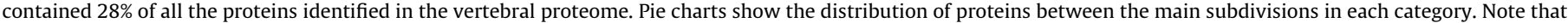

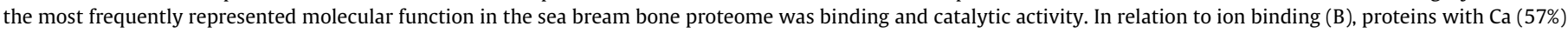
and $\mathrm{Mg}(20 \%)$ binding capacity were the most abundant and the proteins within this category are summarized in Table 1 .

chain 3 and troponin C (Table 2). With the exception of annexin A5 all the identified proteins matched deduced proteins from genes identified in teleosts. GO analysis of the molecular function of $\mathrm{PTHrP}$ responsive proteins indicate involvement in calcium ion binding, collagen binding, metabolism, lipid transport, methionine anabolism and structural molecule activity.

\section{Discussion}

Exploring the bone proteome is an important and challenging task for understanding mechanisms underlying the endocrinological control of its turnover. In this context a partial proteome of sea bream vertebra was generated. Intermittent PTHrP administration caused a significant reduction in both TRACP and ALP activity, although the shift in the ratio of TRACP:ALP was congruent with anabolism. Vertebra is a target tissue for PTHrP action presumably through its receptors PTHR and short-term (5 days) intermittent PTHrP administration provoked a change in the vertebra proteome and significantly $(p<0.05)$ modified the expression of eight proteins.

\subsection{The sea bream bone proteome}

Proteomics of bone tissue is not straight forward because of the structure of bone that makes protein extraction difficult (Lammi et al., 2006). For this reason studies of the bone proteome have mainly focused on in vitro systems using mammalian bone cells such as osteoblasts and osteoclasts (Salasznyk et al., 2005; Wang et al., 2004). Recently, proteomic analysis of proteins extracted directly from mammalian bone has been reported (Fan et al., 2005; Jiang et al., 2007; Pastorelli et al., 2005; Schreiweis et al., 2007). Non-demineralization extraction methods like the one used in the present study (Fan et al., 2005) applied to mammalian bone extract acid-soluble proteins and also maximize the extraction of abundant matrix proteins such as collagens and proteoglycans which probably reduces the identification of low abundance proteins (Hermansson et al., 2004). However, in the sea bream normally abundant mineralized matrix proteins of bone including collagens, osteonectin and osteocalcin were not detected. The failure to detect normally abundant bone proteins in the fish proteome may be because not all protein spots were analysed and/or because of differences 
Table 1

Ion binding proteins categorized by gene ontology analyses.

\begin{tabular}{|c|c|c|c|}
\hline Ion binding $^{\mathrm{a}}$ & GO node ${ }^{a}$ & Protein identity/UniProtKB & Spots $^{\mathrm{c}}$ \\
\hline Calcium & GO:0005509 & $\begin{array}{l}\text { Alpha-actinin-3/088990 } \\
\text { Annexin A13/P27216 } \\
\text { Annexin A3/P12429 } \\
\text { Annexin A5/P17153 } \\
\text { Calmodulin/P62155 } \\
\text { Fucolectin-4/Q9I928 } \\
\text { Myosin light chain 1/Q9IB33 } \\
\text { Myosin light chain 2/P02608 } \\
\text { Parvalbumin beta/P02618, P59747, Q4QY6 } \\
\text { Protein S100-A11/P31949 } \\
\text { Troponin C fast skeletal muscle/Q9I8U8 } \\
\text { Annexin 11b/A0F047 } \\
\text { Putative transient receptor protein 2/Q64210 } \\
\text { Fast skeletal myosin light chain 3/Q9PUT0 } \\
\text { Transketolase/Q6B855 }\end{array}$ & $\begin{array}{l}2 \mathrm{H}, 3 \mathrm{H} \\
12 \mathrm{~L} \\
7 \mathrm{M} \\
50,130,152 \\
10 \mathrm{~J} \\
9 \mathrm{E} \\
1 \mathrm{~L} \\
61 \\
7 \mathrm{~J}, 4 \mathrm{~F} \\
1 \mathrm{~J} \\
65 \\
235 \mathrm{~A} \\
8 \mathrm{~F} \\
64 \\
3 \mathrm{I}\end{array}$ \\
\hline Magnesium & GO:0000287 & $\begin{array}{l}\text { Beta-enolase/P25704 } \\
\text { Phosphoglucomutase-1/Q9D0F9/Q7SXW7 } \\
\text { Enolase A/A4ZDY2 } \\
\text { Enolase 1, (alpha)/Q4TBD1/Q6PC12 }\end{array}$ & $\begin{array}{l}9 \\
5 \mathrm{I}, 20 \\
12 \mathrm{H} \\
8,14,16\end{array}$ \\
\hline Zinc & GO:0008270 & $\begin{array}{l}\text { Carbonic anhydrase 2/Q8UWA5 } \\
\text { Carbonic anhydrase/Q92051 } \\
\text { Betaine homocysteine S-methyltansferase/A2TF10 }\end{array}$ & $\begin{array}{l}5 M \\
76 \mathrm{~A} \\
12\end{array}$ \\
\hline Others & $\begin{array}{l}\text { GO: } 0008430 \\
\text { GO:0046872 } \\
\text { GO:0046872 } \\
\text { GO:0008199 }\end{array}$ & $\begin{array}{l}\text { Selenium-binding protein 2/Q63836 } \\
\text { Transketolase/Q6PB855 } \\
\text { Glyoxalase 1/Q6P696 } \\
\text { Putative transferrin/Q6UPC0 }\end{array}$ & $\begin{array}{l}10 \\
3 \mathrm{I} \\
10 \mathrm{~F} \\
6 \mathrm{H}, 7 \mathrm{H}\end{array}$ \\
\hline
\end{tabular}

a Ion binding molecular function and GO node given by Gene ontology analysis using the GOSlim Viewer (http://www.agbase.msstate.edu/).

b UniprotKB is a protein knowledgebase used to obtain further biological process information (http://www.uniprot.org).

c Spot ID numbers refers to proteins listed in Supplementary Table 1 of the manuscript.

\section{Regulated}

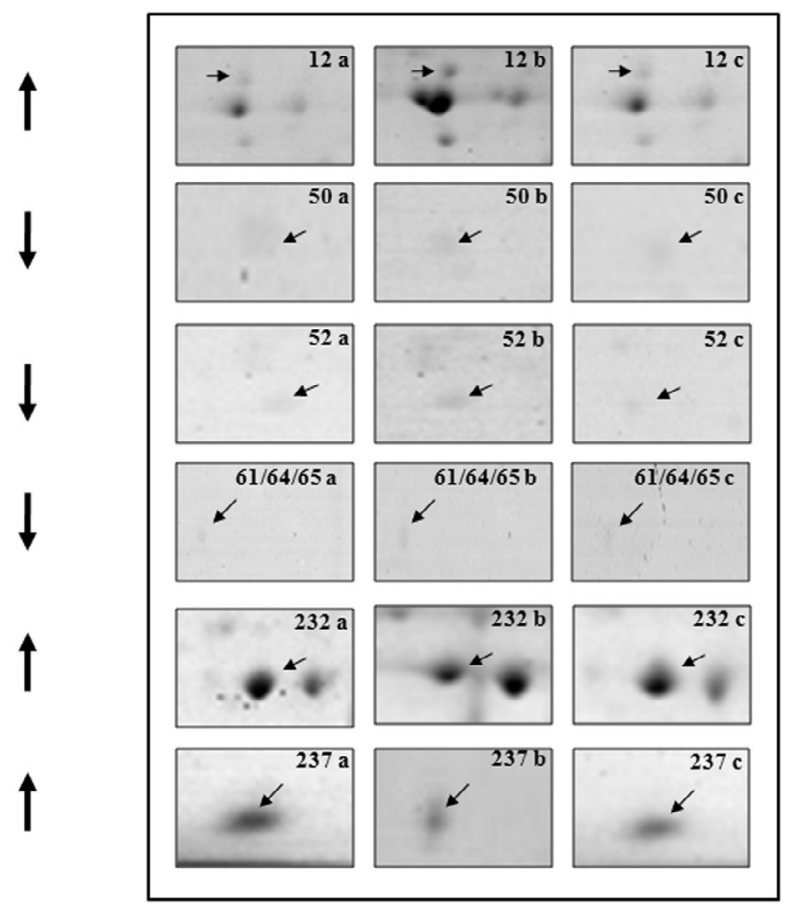

Saline control
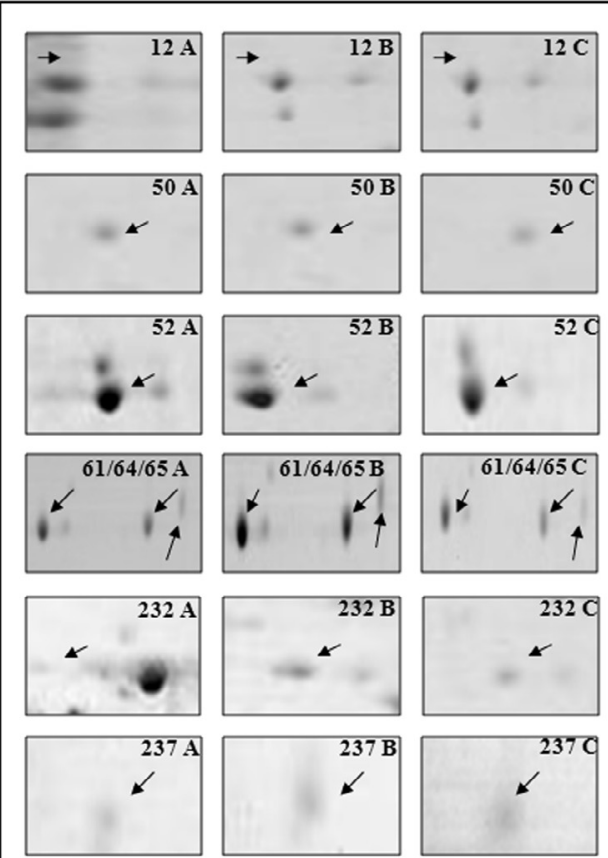

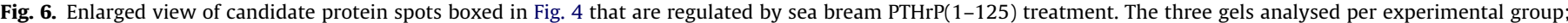

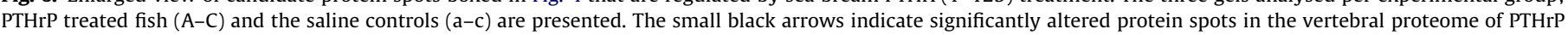

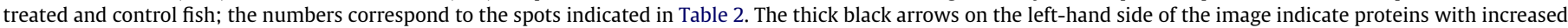
or reduced expression after PTHrP treatment.

in bone characteristics such as its lower Ca content and smaller apatite crystals (Horton and Summers, 2009; Moss, 1961) and its higher lipid content (Hall, 2005; Lall and Lewis-McCrea, 2007).
Moreover, the predicted $\mathrm{pI}$ of proteins in sea bream bone tend to be more acid than the mammalian homologue (Bastone et al., 2009; Fan et al., 2005). 
Table 2

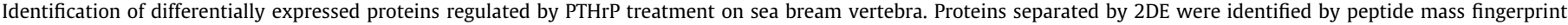
(PMF) and MALDI-TOF/TOF (MS/MS) using the mass peaks spectra of tryptic peptide to search the NCBInr/SwissProt database with MASCOT via BioTools 2.3 software.

\begin{tabular}{|c|c|c|c|c|c|c|c|c|}
\hline Spots $^{\mathrm{a}}$ & Protein identity & Molecular function ${ }^{\mathrm{b}}$ & GI number/species & $\begin{array}{l}\text { Mw/pI } \\
\text { theoretical }^{\mathrm{c}}\end{array}$ & $\begin{array}{l}\text { Mw/pI } \\
\text { determined }^{\mathrm{d}}\end{array}$ & $\begin{array}{l}\text { Sequence } \\
\text { coverage (\%) }\end{array}$ & $\begin{array}{l}\text { Mascote } \\
\text { score }\end{array}$ & $\begin{array}{l}p- \\
\text { Value }^{\mathrm{e}}\end{array}$ \\
\hline \multicolumn{9}{|c|}{ sbPTHrP down-regulated proteins } \\
\hline 50 & Annexin A5 & $\begin{array}{l}\text { Calcium ion binding/ protein binding/ } \\
\text { Collagen binding protein }\end{array}$ & gi|113959/Gallus gallus & $32.4 / 12.6$ & $34 / 4.9$ & 34 & 166 & $2.5^{-17}$ \\
\hline 52 & Apolipoprotein A1 & Metabolism lipid transport & $\begin{array}{l}\text { gi|6686379/Sparus } \\
\text { auratus }\end{array}$ & $29.6 / 5.1$ & $25 / 5.0$ & 66 & 285 & $3.2^{-29}$ \\
\hline 61 & Myosin light chain 2 & $\begin{array}{l}\text { Calcium ion binding/myosin complex } \\
\text { (cytoskeletal) }\end{array}$ & $\begin{array}{l}\text { gi| } 5852838 / \text { Sparus } \\
\text { auratus }\end{array}$ & $19.2 / 4.4$ & $17 / 4.7$ & 91 & 300 & $1^{-30}$ \\
\hline 64 & $\begin{array}{l}\text { Fast skeletal myosin } \\
\text { liht chain } 3\end{array}$ & Calcium ion binding/myosin complex & $\begin{array}{l}\text { gi|5852836/Sparus } \\
\text { auratus }\end{array}$ & $17 / 4.2$ & $16.9 / 4.2$ & 68 & 193 & $5.0^{-20}$ \\
\hline 65 & Troponin C & Calcium ion binding/response stress & gi|1885949/Danio rerio & $18.3 / 3.8$ & $18.3 / 4$ & 37 & 135 & $3.2^{-14}$ \\
\hline \multicolumn{9}{|c|}{ sbPTHrP up-regulated proteins } \\
\hline 12 & $\begin{array}{l}\text { Betaine homocystein } \\
\text { S-methyltransferase }\end{array}$ & Methionine anabolism/ Zinc ion binding & $\begin{array}{l}\text { gi|124020700/ } \\
\text { Paralichthys olivaceus }\end{array}$ & $44.8 / 8.7$ & $44 / 6.9$ & 6 & 142 & $6.3^{-15}$ \\
\hline 232 & $\begin{array}{l}\text { Glial fibrillary acidic } \\
\text { protein }\end{array}$ & Structural molecule activity & gi|20977259/Danio rerio & $42.2 / 4.9$ & $49 / 5.5$ & 23 & 72 & $6.3^{-8}$ \\
\hline 237 & Parvalbumin beta & Calcium ion binding & $\begin{array}{l}\text { gi|32363220/Scomber } \\
\text { japonicus }\end{array}$ & $29.8 / 12.1$ & $13 / 5$ & 16 & 87 & $2^{-9}$ \\
\hline
\end{tabular}

\footnotetext{
a The spot ID numbers refers to proteins listed in Figs. 4 and 6.

b Molecular function of proteins (in some cases several are listed) given by gene ontology analysis using the UniProt database, (http://www.uniprot.org).

c Theoretical molecular weight and isoelectric point determined by MASCOT analysis.

d Observed molecular weight and isoelectric point determined from the localisation of the spots in 2DE.

e $p$-value calculated as $10^{-0.1 * s c o r e}$.
}

Nonetheless a significant number of the proteins identified in sea bream bone were related to bone metabolism, cytoskeleton and energy metabolism. Moreover, ion binding properties of proteins in sea bream vertebra classified and categorized using GO is in general agreement with their high content of calcium, phosphate and carbonate and smaller amounts of magnesium, sodium, strontium, lead, citrate, fluoride, hydroxide, and sulfate (Lall and Lewis-McCrea, 2007). For example, calcium binding proteins were most abundant followed by those binding magnesium and a low percentage of proteins bound zinc and other metals such as selenium. Several of the proteins identified in the sea bream bone proteome have also been described in mammalian bone, these include enolase, apolipoprotein A-1, transferrin, myosin light chain, annexin, S-100 and transketolase (Giner et al., 2007; Jiang et al., 2007; Lammi et al., 2006; Pastorelli et al., 2005; Schreiweis et al., 2007). As expected and in common with the proteome of other teleost tissue many of the proteins identified had a structural function and included, fast skeletal muscle $\alpha$-actin, fast skeletal muscle myosin heavy chain, tropomyosin, keratin type I cytoskeletal $13, \alpha$-actin, creatine kinase, tubulin (Reddish et al., 2008; Schiavone et al., 2008; Sveinsdottir et al., 2008). The only other study of the bone proteome in a teleost is malformed vertebra of white sea bream (Diplodus sargus) but of the 28 proteins differentially expressed compared to normal vertebra, 13 were unidentified limiting its usefulness for the present study (Silva et al., 2010). However, three of the modified proteins (parvalbumin beta, apolipoprotein A1 and myosin light chain 2) identified in malformed vertebra were also modified by PTHrP treatment, and taking into the consideration the importance of this hormone for bone formation, it raises interesting questions about its possible involvement in the aetiology of fish malformations.

The proteins in the sea bream bone reveal the metabolic and functional aspects of fish acellular bone and also its similarity with mammalian bone. For example, collagen $\alpha-2$ type I (COL1A2) and the osteoclastogenesis enzyme related carbonic anhydrase 2 (CAHZ) identified in sea bream bone have well characterized functions in mammalian bone (Cohen, 2006). Similarly, type I collagen a major structural component of the extracellular matrix of mammalian bone, skin and tendons is also present in sea bream (Wahl and Czernuszka, 2006). In mammalian bone COL1A2 is expressed during differentiation to the osteoblastic lineage and during osteoblast maturation and is involved in matrix maturation and mineralization (Cohen, 2006). Mutations in COL1A2 cause bone disease such as osteogenesis imperfect, Ehlers-Danlos syndrome, osteoporosis and Marfan syndrome (Dalgleish et al., 1987; Gajko-Galicka, 2002). The acidifying microenvironment necessary for bone resorption by osteoclasts results from the action of several enzymes, including carbonic anhydrase 2 in humans (Teitelbaum, 2000 ) and its expression is also increased during chondrogenesis (Lammi et al., 2006; Lee et al., 2004). Furthermore, creatine kinase (CK) that is involved in mammalian bone growth and differentiation (Nogami and Oohira, 1987) is also expressed in sea bream bone and one putative CK1 and two putative isoforms of CKM2 (muscle-type creatine kinase) were identified.

Four annexin (ANX) family members (A3, A5, A13, A11b) and 3 isoforms of $A 5$ are identified for the first time in teleost bone. The significance of annexins in bone has not been studied in detail but they are a family of structurally related Ca binding proteins with numerous biological functions. In humans, 12 annexins exist and have a broad tissue distribution including cartilage (A2, A5, A6) and matrix vesicles isolated from chondrocytes where they are proposed to influence matrix mineralization (Giner et al., 2007; Wang et al., 2003). During bone mineralization in mammals, annexin and sodium-phosphate co-transporter $3(\mathrm{NaPi} 3)$ promote accumulation of $\mathrm{Ca}$ and $\mathrm{Pi}$ in matrix vesicles (Kirsch and Claassen, 2000) and A1, A2, A4 and A5 have been implicated in osteoblast differentiation in proteomic studies (Mohiti et al., 1995; Zhang et al., 2007). In addition, A2 enhances osteoclast formation and bone resorption (Takahashi et al., 1994). The function of annexins in fish are poorly characterized but they are implicated in a variety of biological processes and several annexin genes (1-6, 11 and 13) with a wide spread tissue distribution have been identified (Spenneberg et al., 1998; Yeh and Klesius, 1818). A13 is present in the notochord and head rudiment of developing zebrafish (Ozerova and Minin, 2008) and is proposed as the probable common ancestor of all vertebrate annexins and in human it is mainly expressed in kidney and intestinal epithelial cells where it has acquired a highly differentiated intracellular transport function (Choi et al., 2009; Iglesias et al., 2002). 


\subsection{PTHrP and bone homeostasis}

Intermittent administration of PTHrP in vivo to sea bream over 5 days did not modify plasma Ca levels but caused a significant reduction in TRACP and ALP activity, with a shift in the TRACP:ALP ratio from 2.2 in the Control to 1.3 in the PTHrP group indicative of a shift towards anabolism. The results in sea bream are in agreement with in vivo and in vitro studies in mammals that indicate that prolonged or intermittent exposure to PTH or PTHrP has an anabolic action (Castro et al., 2011; Dobnig and Turner, 1995; Kim et al., 2005; Li et al., 2007; McManus et al., 2008; Schiller et al., 1999; Swarthout et al., 2002). In mammals the mid-region and C-terminus of PTHrP are most anabolic (Castro et al., 2011; Toribio et al., 2010) and if region specific effects of PTHrP occur in fish remains to be established.

Despite the observed effects of intermittent PTHrP on TRACP and ALP enzyme activity, neither of the proteins was modified in the bone proteome, and they were presumably among the $>50 \%$ proteins which were not characterised. However, five proteins were down-regulated by sea bream PTHrP(1-125): annexin A5 (ANX5); apolipoprotein A1; myosin light chain 2; fast skeletal myosin light chain 3 ; troponin $C$ and 3 proteins were up-regulated: betaine-homocystein S-methyltransferase; glial fibrillary acidic protein; parvalbumin beta. A common feature of these proteins is their Ca binding function and in mammals annexins play an important role in bone development (Mohiti et al., 1995; Wang et al., 2003; Zhang et al., 2010). For example, ANX5 expression increases during osteogenesis and serves as a Ca channel in the plasma membrane and in matrix vesicles and increases the influx of $\mathrm{Ca}$ which is critical for initiation of mineralization of cartilage and perhaps even bone (Kirsch and Claassen, 2000). A possible consequence of the down-regulation of ANX5 in sea bream bone may be the decrease in ANX5 mediated Ca influx into matrix vesicles of chondrocytes to reduce matrix mineralization. This seems to be coherent with the apparent fall in bone turnover indicated by the reduction of both ALP and TRACP activity in response to 5 days PTHrP administration. Moreover, it may explain the surprisingly low number of differentially expressed proteins caused by intermittent PTHrP exposure in sea bream.

Glial fibrillary acidic protein (GFAP) assembly into intermediate filaments is indirectly blocked by ANX (Arcuri et al., 2002; Garbuglia et al., 1999) and is up-regulated in sea bream bone by PTHrP treatment. In mammalian osteoblasts, PTH also affects the expression of intermediate filaments such as vimentin, $\alpha$-actin and tubulin which are implicated in both, bone resorption and formation (Kim et al., 2005; Lomri and Marie, 1988, 1990). Of the other proteins modified, betaine-homocysteine S-methyltransferase (BHMT) is a zinc metallo-enzyme involved in the regulation of methionine biosynthesis and it is predominantly expressed in liver and kidney of mammals (Pajares and Perez-Sala, 2006). However, in human chondrocyte cell cultures BHMT is an early target gene down-regulated by continuous PTHrP treatment, although its function in chondrocytes has not been established (Hoogendam et al., 2006).

The functional relevance of the remaining proteins regulated by PTHrP in sea bream vertebral bone is unclear but all are Ca ion binders (myosin light chain 2, fast skeletal myosin light chain 3, troponin C, parvalbumin beta) and have previously been detected in vertebrate bone (Fan et al., 2005; Lammi et al., 2006; Silva et al., 2010; Toury et al., 1996; Zhang et al., 2007). In mouse, myosin light chain 2 is present in the bone proteome and is increased by estrogen deficiency (Fan et al., 2005). In mammals, parvalbumin is present in bone cells and the extracellular matrix, principally in calcifying zones of cartilaginous and osseous tissues (Celio et al., 1984; Toury et al., 1996). From the preceding consideration it is clear that to understand how PTHrP acts more studies directed at understanding the biological function of the responsive proteins in bone are required.

In conclusion, a partial proteome of the gilthead sea bream vertebra was characterized and revealed that the most abundant proteins are involved in the binding of proteins and metal/ions (e.g. calcium, magnesium and zinc). In sea bream intermittent PTHrP(1-125) for 5 days did not modify total plasma Ca but caused a reduction in bone turnover as indicated by reduced TRACP and ALP and modified the bone proteome. Most of the 5 proteins down-regulated and 3 proteins up-regulated by intermittent PTHRP are Ca binding proteins which have been implicated in bone development and homeostasis (e.g. ANX5) in mammals. The results of the study unmask novel PTHrP regulated pathways in fish bone and future studies should extend and further validate the results.

\section{Acknowledgments}

The research leading to these results has received funding from the European Community's Seventh Framework Programme (FP7) 2007-2013) under grant agreement no. 222719 - LIFECYCLE. LA was in receipt of a PhD fellowship (SFRH/BD/21973/2005) from FCT and mobility grants from European Commission funded FP6 Network of excellence Marine Genomics Europe (contract GOCECT-2004-505403) and Scientific Support to Policies AQUAGENOME (contract 044481). The authors thank Dr. Johan Gobom and Dr. Eckhard Nordhoff from Mass Spectrometry Group of Department Lehrach, Max Planck Institute-Molecular Genetics for assistance in proteomic analysis and Dorothea Thesis and B. Lukaszew for technical support in 2-DE gel and Mass spectrometry analysis. We thank Angela Ramos for preparation of Fig. 1 and Drs P. Guerreiro, R. Martins and F. Vieira for providing samples and helpful discussions.

\section{Appendix A. Supplementary data}

Supplementary data associated with this article can be found, in the online version, at http://dx.doi.org/10.1016/j.ygcen.2013. 05.014 .

\section{References}

Anjos, L., Rotllant, J., Guerreiro, P.M., Hang, X., Canario, A.V., Balment, R., et al., 2005 Production and characterisation of gilthead sea bream (Sparus auratus) recombinant parathyroid hormone related protein. Gen. Comp. Endocrinol. $143,57-65$

Arcuri, C., Giambanco, I., Bianchi, R., Donato, R., 2002. Annexin V, annexin VI, S100A1 and S100B in developing and adult avian skeletal muscles. Neuroscience 109, 371-388.

Bastone, A., Fumagalli, E., Bigini, P., Perini, P., Bernardinello, D., Cagnotto, A., et al., 2009. Proteomic profiling of cervical and lumbar spinal cord reveals potential protective mechanisms in the wobbler mouse, a model of motor neuron degeneration. J. Proteome Res. 8, 5229-5240.

Bonga, S.E., Pang, P.K.T., 1991. Control of calcium regulating hormones in the vertebrates: parathyroid hormone, calcitonin, prolactin and stanniocalcin. Int. Rev. Citol., 139-213.

de Castro, L.F., Lozano, D., Portal-Nunez, S., Maycas, M., De la Fuente, M., Caeiro, J.R. et al., 2011. Comparison of the skeletal effects induced by daily administration of PTHrP (1-36) and PTHrP (107-139) to ovariectomized mice. J. Cell Physiol. 277, 1752-1760.

Celio, M.R., Norman, A.W., Heizmann, C.W., 1984. Vitamin-D-dependent calciumbinding-protein and parvalbumin occur in bones and teeth. Calcif. Tissue Int. 36, 129-130.

Choi, S.H., Kwon, S.R., Lee, E.H., Kim, K.H., 2009. Molecular cloning, functional characterization and localization of an annexin from a fish gill fluke Microcotyle sebastis (Platyhelminthes: Monogenea). Mol. Biochem. Parasitol. 163, 48-53.

Cohen Jr., M.M., 2006. The new bone biology: pathologic, molecular, and clinical correlates. Am J Med Genet A. 140, 2646-2706.

Dalgleish, R., Hawkins, J.R., Keston, M., 1987. Exclusion of the alpha 2(I) and alpha 1 (III) collagen genes as the mutant loci in a Marfan syndrome family. J. Med. Genet. $24,148-151$. 
Dobnig, H., Turner, R.T., 1995. Evidence that intermittent treatment with parathyroid hormone increases bone formation in adult rats by activation of bone lining cells. Endocrinology 136, 3632-3638.

Fan, Y., Liu, J., Wang, S., Wang, H., Shi, F., Xiong, L., et al., 2005. Functional proteome of bones in rats with osteoporosis following ovariectomy. Life Sci. 76, 28932901.

Fuentes, J., Power, D.M., Canario, A.V., 2010. Parathyroid hormone-related proteinstanniocalcin antagonism in regulation of bicarbonate secretion and calcium precipitation in a marine fish intestine. Am. J. Physiol. Regul. Integr. Comp. Physiol. 299, R150-R158.

Gajko-Galicka, A., 2002. Mutations in type I collagen genes resulting in osteogenesis imperfecta in humans. Acta Biochim. Pol. 49, 433-441.

Garbuglia, M., Verzini, M., Sorci, G., Bianchi, R., Giambanco, I., Agneletti, A.L., et al., 1999. The calcium-modulated proteins, S100A1 and S100B, as potentia regulators of the dynamics of type III intermediate filaments. Braz. J. Med. Biol. Res. 32, 1177-1185.

Giner, R.M., Mancini, L., Kamal, A.M., Perretti, M., 2007. Uneven modulation of the annexin 1 system in osteoblast-like cells by dexamethasone. Biochem. Biophys. Res. Commun. 354, 414-419.

Guerreiro, P.M., Fuentes, J., Canario, A.V., Power, D.M., 2002. Calcium balance in sea bream (Sparus aurata): the effect of oestradiol-17beta. J. Endocrinol. 173, 377385.

Guerreiro, P.M., Renfro, J.L., Power, D.M., Canario, A.V., 2007. The parathyroid hormone family of peptides: structure, tissue distribution, regulation, and potential functional roles in calcium and phosphate balance in fish. Am. J Physiol. Regul. Integr. Comp. Physiol. 292, R679-R696.

Hall, B.K., 2005. Bones and Cartilage: Developmental Skeletal Biology. Academic Press, London.

Hermansson, M., Sawaji, Y., Bolton, M., Alexander, S., Wallace, A., Begum, S., et al. 2004. Proteomic analysis of articular cartilage shows increased type II collagen synthesis in osteoarthritis and expression of inhibin betaA (activin A), a regulatory molecule for chondrocytes. J. Biol. Chem. 279, 43514-43521.

Hoogendam, J., Parlevliet, E., Miclea, R., Lowik, C.W., Wit, J.M., Karperien, M., 2006. Novel early target genes of parathyroid hormone-related peptide in chondrocytes. Endocrinology 147, 3141-3152.

Hoogendam, J., Farih-Sips, H., van Beek, E., Lowik, C.W., Wit, J.M., Karperien, M. 2007. Novel late response genes of PTHrP in chondrocytes. Horm. Res. 67, 159170.

Horton, J.M., Summers, A.P., 2009. The material properties of acellular bone in a teleost fish. J. Exp. Biol. 212, 1413-1420.

Iglesias, J.M., Morgan, R.O., Jenkins, N.A., Copeland, N.G., Gilbert, D.J., Fernandez, M.P., 2002. Comparative genetics and evolution of annexin A13 as the founder gene of vertebrate annexins. Mol. Biol. Evol. 19, 608-618.

Jiang, X., Ye, M., Liu, G., Feng, S., Cui, L., Zou, H., 2007. Method development of efficient protein extraction in bone tissue for proteome analysis. J. Proteome Res. 6, 2287-2294.

Juppner, H., Abou-Samra, A.B., Freeman, M., Kong, X.F., Schipani, E., Richards, J. et al., 1991. A G protein-linked receptor for parathyroid hormone and parathyroid hormone-related peptide. Science 254, 1024-1026.

Karaplis, A.C., Deckelbaum, R.A., 1998. Role of PTHrP and PTH-1 receptor in endochondral bone development. Front Biosci. 3, d795-d803.

Kim, S.H., Jun, S., Jang, H.S., Lim, S.K., 2005. Identification of parathyroid hormoneregulated proteins in mouse bone marrow cells by proteomics. Biochem. Biophys. Res. Commun. 330, 423-429.

Kirsch, T., Claassen, H., 2000. Matrix vesicles mediate mineralization of human thyroid cartilage. Calcif. Tissue Int. 66, 292-297.

Lall, S.P. (Ed.), 2002. The Minerals. Academic Press Inc, San Diego.

Lall, S., Lewis-McCrea, L., 2007. Role of nutrients in skeletal metabolism and pathology in fish - an overview. Aquaculture 267, 3-19.

Lammi, M.J., Hayrinen, J., Mahonen, A., 2006. Proteomic analysis of cartilage- and bone-associated samples. Electrophoresis 27, 2687-2701.

Lee, S.J., Jeon, H.B., Lee, J.H., Yoo, J.S., Chun, J.S., Yoo, Y.J., 2004. Identification of proteins differentially expressed during chondrogenesis of mesenchymal cells. FEBS Lett. 563, 35-40.

Li, X., Liu, H., Qin, L., Tamasi, J., Bergenstock, M., Shapses, S., et al., 2007. Determination of dual effects of parathyroid hormone on skeletal gene expression in vivo by microarray and network analysis. J. Biol. Chem. 282, 33086-33097.

Lomri, A., Marie, P.J., 1988. Effect of parathyroid hormone and forskolin on cytoskeletal protein synthesis in cultured mouse osteoblastic cells. Biochim. Biophys. Acta 970, 333-342.

Lomri, A., Marie, P.J., 1990. Changes in cytoskeletal proteins in response to parathyroid hormone and 1,25-dihydroxyvitamin D in human osteoblastic cells. Bone Miner. 10, 1-12.

McManus, J.F., Davey, R.A., Maclean, H.E., Doust, E.A., Chiu, W.S., Sims, N.A., et al., 2008. Intermittent Fugu parathyroid hormone $1(1-34)$ is an anabolic bone agent in young male rats and osteopenic ovariectomized rats. Bone 42, 1164 1174.

Mohiti, J., Walker, J.H., Caswell, A.M., 1995. Studies on annexins in primary cultures of human osteoblasts and in the human osteosarcoma cell line MG-63. Biochem. Soc. Trans. 23, 36S.

Moss, M.L., 1961. Studies of the acelluar bone of teleost fish. I. Morphological and systematic variations. Acta Anat (Basel). 46, 343-362.

Nogami, H., Oohira, A., Ogasawara, N., 1987. Levels of creatine kinase activity in cartilage of tubular and nontubular bone in relation to pathogenesis of achondroplasia. Clin. Orthop. Relat. Res., 308-311.
Ozerova, S.G., Minin, A.A., 2008. A study of proteins of annexin group in early fish development. IV. Identification of calcium-binding proteins in zebrafish egg by mass spectrometry. Ontogenez 39, 222-226.

Pajares, M.A., Perez-Sala, D., 2006. Betaine homocysteine S-methyltransferase: just a regulator of homocysteine metabolism? Cell. Mol. Life Sci. 63, 2792-2803.

Pastorelli, R., Carpi, D., Airoldi, L., Chiabrando, C., Bagnati, R., Fanelli, R., et al., 2005. Proteome analysis for the identification of in vivo estrogen-regulated proteins in bone. Proteomics 5, 4936-4945.

Persson, P., Takagi, Y., Bjornsson, B.T., 1995. Tartrate-resistant acid-phosphatase as a masker for scale resorption in rainbow-trout, oncorhynchus-mykiss - effects of estradiol-17-beta treatment and refeeding. Fish Physiol. Biochem. 14, 329-339.

Reddish, J.M., St-Pierre, N., Nichols, A., Green-Church, K., Wick, M., 2008. Proteomic analysis of proteins associated with body mass and length in yellow perch Perca flavescens. Proteomics 8, 2333-2343.

Redruello, B., Estevao, M.D., Rotllant, J., Guerreiro, P.M., Anjos, L.I., Canario, A.V., et al., 2005. Isolation and characterization of piscine osteonectin and downregulation of its expression by PTH-related protein. J. Bone Miner. Res. 20, 682-692.

Rotllant, J., Worthington, G.P., Fuentes, J., Guerreiro, P.M., Teitsma, C.A., Ingleton, P.M., et al., 2003. Determination of tissue and plasma concentrations of PTHrP in fish: development and validation of a radioimmunoassay using a teleost 1-34 N-terminal peptide. Gen. Comp. Endocrinol. 133, 146-153.

Rotllant, J., Redruello, B., Guerreiro, P.M., Fernandes, H., Canario, A.V., Power, D.M., 2005. Calcium mobilization from fish scales is mediated by parathyroid hormone related protein via the parathyroid hormone type 1 receptor. Regul. Pept. 132, 33-40.

Rubin, D.A., Juppner, H., 1999. Zebrafish express the common parathyroid hormone/ parathyroid hormone-related peptide receptor (PTH1R) and a novel receptor (PTH3R) that is preferentially activated by mammalian and fugufish parathyroid hormone-related peptide. J. Biol. Chem. 274, 28185-28190.

Rubin, D.A., Hellman, P., Zon, L.I., Lobb, C.J., Bergwitz, C., Juppner, H., 1999. A G protein-coupled receptor from zebrafish is activated by human parathyroid hormone and not by human or teleost parathyroid hormone-related peptide. Implications for the evolutionary conservation of calcium-regulating peptide hormones. J. Biol. Chem. 274, 23035-23042.

Salasznyk, R.M., Westcott, A.M., Klees, R.F., Ward, D.F., Xiang, Z., Vandenberg, S., et al., 2005. Comparing the protein expression profiles of human mesenchymal stem cells and human osteoblasts using gene ontologies. Stem Cells Dev. 14, 354-366.

Schiavone, R., Zilli, L., Storelli, C., Vilella, S., 2008. Identification by proteome analysis of muscle proteins in sea bream (Sparus aurata). Eur. Food Res. Technol. 227, 1403-1410.

Schiller, P.C., D’Ippolito, G., Roos, B.A., Howard, G.A., 1999. Anabolic or catabolic responses of MC3T3-E1 osteoblastic cells to parathyroid hormone depend on time and duration of treatment. J. Bone Miner. Res. 14, 1504-1512.

Schreiweis, M.A., Butler, J.P., Kulkarni, N.H., Knierman, M.D., Higgs, R.E., Halladay, D.L., et al., 2007. A proteomic analysis of adult rat bone reveals the presence of cartilage/chondrocyte markers. J. Cell. Biochem. 101, 466-476.

Silva, T.S., Cordeiro, O., Richard, N., Conceicao, L.E., Rodrigues, P.M., 2010. Changes in the soluble bone proteome of reared white seabream (Diplodus sargus) with skeletal deformities. Comp. Biochem. Physiol., Part D: Genomics Proteomics 6, 82-91.

Spenneberg, R., Osterloh, D., Gerke, V., 1998. Phospholipid vesicle binding and aggregation by four novel fish annexins are differently regulated by $\mathrm{Ca}^{2+}$. Biochim. Biophys. Acta 1448, 311-319.

Sun, Z.F., Jiang, H., Ye, Z.Q., Jia, B., Zhang, X.L., Zhang, K.Q., 2009. Expression of Rho GDIalpha in rat osteoblasts intermittently exposed to parathyroid hormone in vitro and in vivo. Acta Pharmacol. Sin. 30, 1001-1007.

Suzuki, N., Suzuki, T., Kurokawa, T., 2000. Suppression of osteoclastic activities by calcitonin in the scales of goldfish (freshwater teleost) and nibbler fish (seawater teleost). Peptides 21, 115-124.

Sveinsdottir, H., Vilhelmsson, O., Gudmundsdottir, A., 2008. Proteome analysis of abundant proteins in two age groups of early Atlantic cod (Gadus morhua) larvae. Comp. Biochem. Physiol., Part D: Genomics Proteomics 3, 243-250.

Swarthout, J.T., D’Alonzo, R.C., Selvamurugan, N., Partridge, N.C., 2002. Parathyroid hormone-dependent signaling pathways regulating genes in bone cells. Gene 282, 1-17.

Takahashi, S., Reddy, S.V., Chirgwin, J.M., Devlin, R., Haipek, C., Anderson, J., et al., 1994. Cloning and identification of annexin II as an autocrine/paracrine factor that increases osteoclast formation and bone resorption. J. Biol. Chem. 269, 28696-28701.

Teitelbaum, S.L., 2000. Bone resorption by osteoclasts. Science 289, 1504-1508.

Toribio, R.E., Brown, H.A., Novince, C.M., Marlow, B., Hernon, K., Lanigan, L.G., et al., 2010. The midregion, nuclear localization sequence, and $C$ terminus of PTHrP regulate skeletal development, hematopoiesis, and survival in mice. FASEB J. 24, 1947-1957.

Toury, R., Belqasmi, F., Hauchecorne, M., Heizmann, C.W., Balmain, N., 1996. Ultrastructural localization of alpha-parvalbumin in the epiphyseal plate cartilage and bone of growing rats. Bone 19, 245-253.

Vieira, F.A., Pinto, P.I., Guerreiro, P.M., Power, D.M., 2012. Divergent responsiveness of the dentary and vertebral bone to a selective estrogen-receptor modulator (SERM) in the teleost Sparus auratus. Gen. Comp. Endocrinol. 179, 421-427.

Wahl, D.A., Czernuszka, J.T., 2006. Collagen-hydroxyapatite composites for hard tissue repair. Eur. Cell Mater. 11, 43-56.

Wang, W., Xu, J., Kirsch, T., 2003. Annexin-mediated $\mathrm{Ca}^{2+}$ influx regulates growth plate chondrocyte maturation and apoptosis. J. Biol. Chem. 278, 3762-3769. 
Wang, D., Park, J.S., Chu, J.S., Krakowski, A., Luo, K., Chen, D.J., et al., 2004. Proteomic profiling of bone marrow mesenchymal stem cells upon transforming growth factor beta1 stimulation. J. Biol. Chem. 279, 43725-43734.

Witten, P.E., Huysseune, A., 2009. A comparative view on mechanisms and functions of skeletal remodelling in teleost fish, with special emphasis on osteoclasts and their function. Biol. Rev. Camb. Philos. Soc. 84, 315-346.

Yeh, H.Y., Klesius, P.H., 1818. Identification, phylogenetic relationships, characterization and gene expression patterns of six different annexins of channel catfish (Ictalurus punctatus Rafinesque. Vet. Immunol. Immunopathol. 136 (2010), 176-183.
Zhang, A.X., Yu, W.H., Ma, B.F., Yu, X.B., Mao, F.F., Liu, W., et al., 2007. Proteomic identification of differently expressed proteins responsible for osteoblast differentiation from human mesenchymal stem cells. Mol. Cell. Biochem. 304, 167-179.

Zhang J.H. Fu, J.X, Zhang, X.H. Sun, Y, 2007. Effects of the osteoclast in pathogenesis of multiple myeloma. Zhonghua Xue Ye Xue Za Zhi 28, 323-326.

Zhang, H., Recker, R., Lee, W.N., Xiao, G.G., 2010. Proteomics in bone research. Expert Rev. Proteomics 7, 103-111. 